ORIGIN AND IDENTITY:

\title{
REREADING EXODUS AS A POLEMICAL NARRATIVE THEN (PALESTINE) AND NOW (AFRICA) ${ }^{1}$
}

\author{
Hendrik Bosman \\ Department of Old en New Testament \\ Stellenbosch University
}

\begin{abstract}
For several decades the book of Exodus was the locus classicus for the struggle against colonialism and racial discrimination across Africa. This paper engages with the problem: How do we appropriate the book of Exodus theologically in a post-colonial Africa? The validity of the following hypothesis will be investigated: The book of Exodus can be interpreted as a polemical narrative concerned with origin of Israel as a nation, born within the crucible of slavery and forged by the guiding divine presence during the sojourn in the desert and at Mount Sinai. It is argued that there are similarities between elements of the Exodus narrative and certain texts in the Ancient Near East-specific attention will be given to the three major themes of the Baal epic: The crossing of the Re(e)d Sea (Ex 14-15) and Baal's victory over Yam (sea); the instructions concerning the tabernacle and the eventual building of the tabernacle (Ex 25-31, 35-40) and the arguments for building a temple or palace for Baal; as well as the destruction of the golden calf (Ex 32-34) and the annihilation of Mot (death) by Anat. Brief mention is also be made of correspondences between the narratives in Exodus and certain Assyrian and Neo-Babylonian texts. In all these contexts it is suggested that Yahweh is portrayed as the deity that played a crucial role in the origin of Israel as a nation and that this was constitutive for emerging monotheism as the religious identity of Israel as a nation. In closing it will be reflected on how African narratives concerning origin and identity can engage in an intertextual dialogue with the Exodus narrative.
\end{abstract}

Key concepts: Book of Exodus, Identity, Intertextuality, Polemical Narrative

\section{Introduction}

For several decades the book of Exodus was the locus classicus for the struggle against colonialism and racial discrimination across Africa. This paper engages with the problem: How do we appropriate the book of Exodus theologically in a post-colonial Africa? The validity of the following hypothesis will be investigated: The book of Exodus can be interpreted as a polemical narrative concerned with origin of Israel as a nation, born within the crucible of slavery and forged by the guiding divine presence during the sojourn in the desert and at Mount Sinai. ${ }^{2}$

\footnotetext{
This contribution forms part of a research project on The reinterpretation of the Book of Exodus in Africa and must be read in relation to the contributions made by Dr Edwin Zulu (Zambia) and Rev Jonathan Weor (Nigeria).

I considered the possible use of myth instead of narrative but decided against it due to the perception that " $m y t h$ is too fraught with historical and ideological baggage to be a useable concept in contemporary discussion" (Green 1990:22). Although one is well reminded that "myth" was one of the most important vehicles available for biblical writers to do their theologizing (Batto 1992: 1).
} 
It is argued that there are similarities between elements of the Exodus narrative and certain texts in the Ancient Near East - specific attention will be given to the three major themes of the Baal Cycle (KTU 1.1-1.6): The crossing of the Re(e)d Sea (Ex 14-15) and Baal's victory over Yam (sea); the instructions concerning the tabernacle and the eventual building of the tabernacle (Ex 25-31,35-40) and the arguments for building a temple or palace for Baal; as well as the destruction of the golden calf (Ex 32-34) and the annihilation of Mot (death) by Anat. Brief mention is also be made of correspondences between the narratives in Exodus and certain Assyrian and Neo-Babylonian texts. In all these contexts it is suggested that Yahweh is portrayed as the deity that played a crucial role in the origin of Israel as a nation and that this was constitutive for emerging monotheism as the religious identity of Israel as a nation. In closing it will be reflected on how African narratives concerning origin and identity can engage in an intertextual dialogue with the Exodus narrative.

Post-apartheid South Africa is still riddled with extreme forms of nationalism and racism, but recently xenophobia has been added to our list of national calamities. I trust that this research concerned with the construction of identity in ancient Israel, will have some bearing on similar problems of our time.

\section{Polemical Narratives on Origin and Identity}

The hypothesis of this contribution that the book of Exodus can be interpreted as a polemical narrative concerned with the origin of Israel as a nation, presumes a polemic that is more covert than overt. To conjecture about the existence of a hidden polemic one requires an argument that indicates the existence of a controversial subject. Such a conjecture concerned with a hidden polemic embedded in a narrative will be considerably strengthened by evidence that a similar polemic can be found in a variety of biblical materials (Amit 2000: 93-97).

I consider most of the Old Testament to be characterized by a rhetoric that tries to convince a polytheistic target audience that they should convert to or remain loyal to Yahwistic monotheism. The emergence of Yahwism took place in Palestine during the time of the Israelite and Judean monarchies and had to be sustained against the Assyrian onslaught during the latter days of the Judean monarchy. Loyalty to Yahwism was especially crucial during the exile when Babylonian polytheism threatened to swamp the monotheism of the exiles and resistance was required to survive the onslaught.

It seems to me to be possible to argue that not only the creation narratives of Genesis 13, but also major sections of the book of Exodus contain a ongoing but less obtrusive polemic against contending Canaanite, Assyrian and Neo-Babylonian (perhaps even Persian!?) mythologies concerning humankind's origin and identity. Therefore the question that requires careful attention is: Can we identify enough evidence in the book of Exodus that points towards the existence a polemic against various versions of polytheism in different parts of Exodus.

The slippery term "identity" is used differently in various academic disciplines. Therefore a term linked to identity such as "Israel", can be used as a territorial, a religious, as socio-political, as well as an ethnic designation (Skjeggestad 1992: 161-162; Bosman 2004: 58-61). Knauf (1994: 188-189) is of the opinion that several "Israels" can be described up to the Persian period:

a) The earliest reference to Israel is on the $13^{\text {th }}$ century BCE Merneptah stele that refers briefly to a group in Palestine known as Israel. 
b) The ten tribes that were consolidated during the $9^{\text {th }}$ century BCE to became the Northern Kingdom of Israel and were destroyed by the Assyrians in 720 BCE.

c) The southern Kingdom of Judah took over the name of Israel as the people of Yahweh after $720 \mathrm{BCE}$ and the description of the nation about to cross the Jordan before entering the Promised Land was rooted in the deuternomistic perspectives on Israel.

d) During and after the Babylonian exile, exclusive definitions of Israel were on the increase and a "Persian Israel" emerged.

\section{Exodus 14-15 as a Polemical Narrative}

The crossing of the Re(e)d Sea is described in prose in Exodus 14 and in the poetic songs of triumph by Moses and Miriam in the following chapter 15. These two chapters delineate the border between slavery in Egypt and the gradual formation of Israel as a nation during the wilderness wandering, the theophany at Sinai, the design and building of the tabernacle and the golden calf episode.

Like Yahweh, Baal is also depicted as the divine warrior who is victorious over the sea using clubs to repeatedly strike the sea (Yamm) - almost beating it into submission (Coogan 1978: 88-89):

Strike Prince Sea on the shoulder,

Judge River between the arms...

Strike Prince sea on the skull,

Judge River between the eyes.

Sea will stumble,

he will fall to the ground...

Baal captured and drank Sea;

He finished of Judge River.

Smith (1994: 323) has a somewhat different translation of the last line (KTU 1.2.27):

Baal drags and dismembers (?) Yamm,

He destroys Judge River.

The Exodus narrative has a similar ring to it when the Lord commands Moses:

Rise your staff and stretch your hand over the sea to divide the water... (Ex 14: 16)

Then Moses stretched out his hand over the sea, and all that night the Lord drove the sea back with a strong east wind... (Ex 14: 21).

In contrast to Baal, Yahweh, does not command Moses to strike the sea, but to stretch his arm over the sea and split it (Sarna 1001:73). It is possible that one here has an indirect reference to the power of God who does not require the striking of the sea - as Baal did?

\section{Exodus 19-21 as a Polemical Narrative}

After the crossing of the sea, leading up to the design and building of the tabernacle, one should also take note of the pivotal description of the theophany of Yahweh on Mount Sinai. Like Yahweh, Baal also revealed him on a mountain as part of a storm and there is similar imagery used in both accounts (Coogan 1978: 20): 
There was thunder and lightning and a heavy cloud on the mountain. ...Mount Sinai was covered in smoke, because Yahweh had descended upon it in fire...And the whole mountain quaked violently (Exodus 19: 16-18).

Then Baal opened a slit in the clouds,

Baal sounded his holy voice,

Baal thundered from his lips...

The earth's high places shook.

Jeremias (1965: 78-83) found many references in Assyrian and Babylonian texts containing theophanic elements such as thunder, earthquakes and the shaking of the heavens. The NeoAssyrian liturgy to Adad is a good example (Van Seters 1994: 256-257):

When the lord is angered the heavens tremble before him ... when he rages, the earth wakes before him; the great mountains are shattered before him. At his raging, at his wrath, at his roaring, at his thunder, the gods of heaven ascend to heaven, the gods of th earth enter the earth...

\section{Exodus 25-31 \& 35-40 as Polemical Narrative}

It has long been an intriguing question for me concerning the interpretation of the book of Exodus: What is the function of the elaborate and extensive detail given to the design of the tabernacle (Ex 25-31) and the eventual painstaking building of the tabernacle according to the minute detail of its design (Ex 35-40)?

Like Yahweh, Baal also has a temple or house that is built for him. Repeatedly the goddess Asherah and her sons shout (Coogan 1978: 20, 96, 100):

But Baal has no house like the other gods',

no court like Asherah's sons'

Eventually the god El replies (Coogan 1978: 101):

Let a house like the other gods' be built for Baal, a court like Asherah's sons'.

After Baal collects silver, gold and jewels he calls for Kothar-wa-Hasis, the craftsman of the gods (like Bezalel and Oholiab), to start with the construction of his palace (Coogan 1978: 102):

Kothar, hurry, build a house; hurry, erect a palace;

hurry, build a house; hurry, raise a palace among the peaks of Zaphon.

In the end the craftsman, Kothar, can report to Baal (Coogan 1978: 103):

They built his house, they erected his palace;

They went to the Libanon for wood, to Sirion for the finest cedar... 


\section{Exodus 32-34 as a Polemical Narrative}

The narrative concerning the golden calf is framed by instructions to observe the Sabbath (Ex 31: 12-18; 35: 1-3), one of the most important commandments related to identity. During the exile and post-exilic period, the keeping of the Sabbath as well as circumcision, were important mechanisms to maintain identity.

A more extended frame for the golden calf episode is found in the calling of Bezalel and Oholiab, the chief craftsmen responsible for the construction of the tabernacle (Ex 31: 1-11; 35: 30-36:7). Last but not least, one should also keep in mind that the golden calf episode is also framed by the instructions to build the tabernacle (Ex 25-31) and the description of the building the tabernacle according to its instructions (Ex 35-40).

Attempts have been made to relate the destruction of the golden calf with the Ugaritic description of how Mot is destroyed by Anat "by means of several actions of burning, splitting, grinding, scattering and either feeding the birds with the remains or throwing them in the sea" (van Seters 1994: 304). According to the very readable translation of the Baal Epic by Coogan (1978:112) the killing of Mot by Anat is described as follows:

She seized El's son Death:

with a sword she split him;

with a sieve she winnowed him;

with fire she burned him;

with a hand mill she ground him;

in the fields she sowed him.

May the birds not eat his remains,

may the fowl not consume his parts:

let flesh cry out to flesh!

The destruction of the golden calf by Moses is described in the following way:

And he took the calf they had made and burned it in the fire; then he ground it into powder, scattered it on the water and made the Israelites to drink it (Ex 32:20).

The comparison between Exodus and Ugaritic description of Baal's destruction suggest a common concern to "heaping up every imaginable sort of destructive action" to establish total and complete annihilation of an adversary (Begg 1985: 208-209). ${ }^{3}$

\section{Rereading Exodus as a Polemical Narrative in Africa}

This paper engages with the problem: How do we appropriate the book of Exodus theologically in a post-colonial Africa? It is my contention that the book of Exodus can be reread as a text that goes beyond liberation. Despite the fact that Exodus has been stereotyped as the locus classicus for the struggle against colonialism and racial discrimination across Africa; it can (and should!) be reread as a narrative that concerns religious origin and monotheistic identity using polemic rhetoric to counter ongoing polytheistic alternatives.

It is well known that there are all over Africa narratives concerning national or ethnic origin and identity. During this congress two other paper will address the possibility that

\footnotetext{
N Wyatt (1998: 135) refers to several other examples of an almost ritual procedure of annihilation and destruction: The Egyptian Pyramid Text 292; Sennacherib's punishment of his grandfather's assasins (ANET 288) and Plutarch's De Iside 73.
} 
these African narratives concerning origin and identity can engage in an intertextual dialogue with the Exodus dialogue. ${ }^{4}$

There are many narratives in Africa concerning the origin of humankind. Mbiti (1975:92) in his reflection on "the creation and original state of man" makes the following important observation:

Man is at the very centre of existence, and African peoples see everything else in relation to this central position of man. God is the explanation of man's origin and sustenance: It is as if God exists for the sake of man.

The proposed intertextual dialogue between the Book of Exodus as polemical narrative advocating monotheism and the kingship of Yahweh and predominantly anthropocentric African narratives about origin and identity can stimulate the radical theological challenge of anthropocentric presuppositions.

Due to the immediate context of this congress I thought it appropriate to briefly reflect on the covenant made by the Voortrekkers and how the battle of Blood River (16 December 1838) resembles a narrative concerning origin and identity that needs to be challenged by the Exodus as polemical narrative.

The bare facts of these events are: Led by Sarel Cilliers, the Voortrekkers during their preparations for a military showdown with the Zulu army, on 9 December 1838 "made a vow that if God granted the men victory, they and their descendants would commemorate the day of the battle and would build a church" (Giliomee 2003: 165). On 16 December 1838 Andries Pretorius and about 500 men defeated approximately 12000 Zulu warriors during the battle at Blood River. Giliomee (2003: 165) is of the opinion that Afrikaner nationalism of the next century considered Blood River the battle that "saved" the trek and secured the victory of Christianity and "civilization". In accordance to the covenant a Church of the Vow was built in Pietermaritzburg, but the public celebration of the vow was discontinued until 1880 when Paul Kruger was instrumental in reviving it (Giliomee 2003: 166).

In a commemorative publication 150 years after the making of the covenant, Botes (1988:83) is adamant that the Day of the Covenant played a crucial role in Afrikaners becoming a nation and that it constituted the beginning of Afrikaner Christian nationalism truly a narrative concerning origin and identity. ${ }^{5}$ What would intertextual dialogue between the narratives concerning the Day of the Vow and the battle of Blood River and the book of Exodus amount to? I would hope that ideological presuppositions will be challenged and that civil religion will be exposed.

I now turn to a few examples of African responses to Exodus and the appropriateness of the liberation paradigm in post-colonial Africa:

Marc Ela (1991: 256) poses the question: "What is the message of the Book of Exodus today for millions of Africans in their religious, cultural, political and socio-economic situations?" His answer entails a reading of Exodus that "enter into solidarity with individuals and groups who are refused the dignity of being human, to denounce the abuses of established systems and to intervene to protect the weak..." (Ela 1991:256). For Ela (1991: 264) "the prime interest in reading the Book of Exodus is to rescue the majority of African Christians from ignorance of the history of liberation. After all, this text is about nothing else."

4 These two papers are: Jonathan Weor (M'Kar, Nigeria) - Narratives of the origin and migration of the Tiv people as indigenous resources for the interpretation of the book of Exodus; and Edwin Zulu (Lusaka, Zambia) - Interpreting Exodus from the perspective of Ngoni narratives concerning origin

5 The subtitle of the commemorative publication concerning the Day of the Vow is significant: Historiese gebeure en verpligtende werklikheid = "Historical events and obligating reality". 
Jesse Mugambi has argued that the liberation paradigm has attracted the attention of many African theologians due to "the historical experience of colonial and neo-colonial domination" and that this justified the emphasis on the liberation theme as an Exodus from colonial bondage (Mugambi 2002: 190-195; Dedji 2003:49). Due to the historical, cultural, ideological and religious distance between the events of the Exodus and the African experience of colonialism "the parallels drawn between the Exodus and the process of decolonization have been far-fetched." In short Mugambi's position with regards to the Exodus motif in liberation theology boils down to the following (Dedji 2003: 52):

- The parallels drawn between the Exodus and decolonization have been contrived and far-fetched.

- He is concerned with the "selective" and "naïve" use of only one small section in the whole of the Exodus - especially Exodus 3: 7-10. ${ }^{6}$

This leads to Mugambi's plea: "A time has come for African Christians to discern themes other than liberation and the Exodus to stimulate their own involvement in history" (Dedji 2003: 55).

In an article recently published by Madipoane Masenya (ngwana' Mphahlele) titled: Liberation with us? Re-reading the Book of Exodus in a post-apartheid South Africa, she asks the following questions:

- How sufficient is the Exodus model of God as liberator in addressing the plight of the Black masses?

- Can the Exodus model of God as liberator be applied with success to the present postapartheid South Africa?

Masenya argues that the portrayal of Yahweh both as liberator (God of the Exodus) and dispossessor (God of the conquest) in the book of Exodus is confusing at best. As alternative she suggests that Exodus is re-read from the perspective of African- and South African women's experiences since it can yield new insights regarding the liberation of the marginalized. Although the Book of Exodus was "a preferred book in South African Black theological discourses" no one from this group focused on the whole book (Masenya 2005:5).

According to Masenya (2005:11) Black South African Bible readers will "heartily embrace the image of YHWH as the One who sides with the oppressed poor, particularly in view of the political liberation that has been acquired in recent years, they will however, find it difficult to identify with the portrayed image of YHWH as dispossessor." Masenya (2005: 18-19) concludes that "the theological struggle which was begun by Black theologians and biblical scholars in the early seventies for the liberation of the Black masses is far from being accomplished" since gender inequality, racism, classism and xenophobia is still alive and well in post-apartheid South Africa.

I would like to add my voice to Maluleke's evaluation that "African women's theology has been by far the most prolific and challenging in the past decade and a half - at least in Anglophone Protestant Africa" (2002: 160).

Ex 3: 7-8a: Then Yahweh said, "I have observed the misery of my people who are in Egypt; I have heard their cry on account of their taskmasters. Indeed, I know their sufferings, and I have come down to deliver them form the Egyptians, and to bring them out of that land to a good and spacious land". 


\section{Conclusion}

It is clear that there are numerous resemblances between the book of Exodus and Canaanite, Assyrian and Babylonian mythology - enough to suggest an ongoing polemic between the monotheistic Yahwist believing community and ANE polytheistic alternatives. To my mind it is not clear that "consciously or unconsciously, Israel recycled an old mythological plotline as historiography" (contra Propp 1999: 560).

The narratives describing the Exodus events echo throughout the history of Israel as a nation and of the post-exilic Jewish believing communities. "It was a recurring experience in which the nation was renewed and recreated, regardless of who the oppressor nation might be" (Matthews 2002: 15).

In essence I would like to agree with Mugambi's concern with the selective and naïve use of the Exodus narrative, as well as the need to consider alternative paradigms such as reconstruction, restoration and rehabilitation. However, I would like to caution any attempt to ignore the Book of Exodus due to the selective and naïve use by certain liberation theologians. Rereading Exodus as polemical narrative that challenges co-existing narratives concerning origin and identity has potential to make a constructive impact on the ongoing African theological debate.

At the beginning of the $21^{\text {st }}$ Century theological reflection in Africa is still in search of theoretical tools and methodologies that go beyond the well worn (worn out?) liberation hermeneutics. Just perhaps, the rereading of the Book of Exodus as a polemical narrative invites challenging intertextual dialogue with numerous African narratives concerning origin and identity. ${ }^{8}$ This intertextual challenge can inform the crucial task of "being prophetic in post-independent Africa" (Maluleke 2002: 147, 159).

Monotheism as an emerging property of religion is still occurring in our time and our theological reflection should enhance this ongoing unfolding of monotheism (Gnuse 1997: 275). The polemical narrative embedded in the book of Exodus can contribute to facilitate the journey from indigenous narratives on origin and identity to contextually relevant monotheism - a religion that is obviously Christian and undeniably African.

\section{BIBLIOGRAPHY}

Amit, Y 2000. Hidden Polemics in Biblical narrative. (Biblical Interpretation Series 25). Leiden: Brill.

Batto, BF 1992. Slaying the dragon. Mythmaking in the Biblical tradition. Louisville: Westminster/John Knox.

Begg, CT 1985. "The destruction of the calf (Exod 32, 20 and Deut 9, 21)", in (ed.) N Lohfink), Das Deuteronomium. Leuven: Peters, 208-251.

Bosman, JP 2004. Social identity in Nahum: A theological-ethical enquiry. Stellenbosch: Unpublished DTh dissertation.

\footnotetext{
"Ultimately the purpose of myth is to expose and admit the paradoxes which lie at the heart of human societies... myths are not monolithic constructions, imposing a particular view of the world... but rather they function more as therapies for societies radically at odds with themselves" (Riches 2000: 54).

8 I consider this most appropriate in the year during which we conclude the second decade after the writing of the Kairos Document.
} 
Botes, HJ 1988. “Geloftedag se betekenis deur die jare heen”, in AD Pont (red.), Die Gelofte van 1838 - Historiese gebeure en verpligtende werklikheid. Pretoria: Kital, 83-95.

Coogan, MD 1978. Stories from Ancient Israel. Philadelphia: Westminster.

Dedji, V 2003. Reconstruction and renewal in African Christian Theology. Nairobi: Acton.

Ela, J-M 1991. "A Black African perspective: An African reading of Exodus" in RS Sugirtharajah (ed.), Voices from the margin. Interpreting the Bible in the Third World. Maryknoll: Orbis, 256-266.

Giliomee, H 2003. The Afrikaners. A biography of a people. Cape Town: Tafelberg.

Gnuse, RK 1997. No other Gods. Emergent monotheism in Israel. (JSOT 241). Sheffield: SJOT.

Green, G 1990. "Myth, History and Imagination: The creation narratives in Bible and Theology". HBT 12, 19-38.

Jeremias, J 1965. Theophanie: Die Geschichte einer alttestamentlichen Gattung. (WMANT 10). Neukirchen-Vluyn.

Knauf, EA 1994. Die Umwelt des Alten Testaments. (NSK - AT 29). Stuttgart: Katolisches Bibelwerk.

Maluleke, TS 2002. "The rediscovery of the agency of Africans. An emerging paradigm of post-cold war and post-apartheid black and African theology" in E Katongole (ed.) African Theology Today. Scranton: Univ Press, 147-169.

Masenya (ngwana' Mphahlele), M 2005. "Liberation with us? Re-reading the Book of Exodus in a post-apartheid South Africa". Nigerian Journal of Biblical Studies. 19: 1-14.

Matthews, VH 2002. A Brief history of ancient Israel. Louisville: Westminster/John Knox.

Mbiti, JS 1975. African Religions \& Philosophy. London: Heinemann.

Mugambi, JNK 2002. "From liberation to reconstruction" in E Katongole (ed.) African Theology Today. Scranton: Univ Press, 189-206.

Mugambi, JNK 2003. Christian Theology and social reconstruction. Nairobi: Acton.

Propp, WHC 1999. Exodus 1-18 (The Anchor Bible). New York: Doubleday.

Riches, JK 2000. Conflicting Mythologies. Identity formation in the Gospels of Mark and Matthew. Edinburgh: Clark.

Sarna, NM 1991. Exodus (JPS Torah Commentary). Philadelphia: JPS.

Skjeggestad, M 1992. "Ethnic groups in early Iron Age Palestine: some remarks on the use of the term 'Israelite' in recent research." Scandinavian Journal of the Old Testament 6/2: 159-186.

Smith, MS 1994. The Ugaritic Baal Cycle. Vol I (SVT 55). Leiden: Brill.

Van Seters, J 1994. The life of Moses. The Yahwist as historian in Exodus-Numbers. Louisville: Westminster/John Knox.

Wyatt, N 1998. Religious texts from Ugarit. The words of Ilimilku and his colleagues. (The Biblical Seminar 53). Sheffield: Sheffield Academic Press. 